Arch. histol. jap., Vol. 38, No. 3 (1975)

p. $229-235$

Department of Anatomy (Prof. H. OuTi), Okayama University School of Medicine, Okayama, Japan

\title{
Scanning Electron Microscopy of Tannin-Osmium Treated and Resin-Embedded Specimens, A Demonstration of Transmural Passage of Blood Cells in the Bone Marrow
}

\author{
Takuro MuRAKAMI
}

Received June 9, 1975

\begin{abstract}
Summary. Tissue pieces were made conductive by osmium impregnation (revised tannin-osmium method of MURAKAMI, 1974) and embedded in hydroxy ethyl methacrylate. The resin-embedded specimens were cracked and observed, with neither elimination of resin nor metal coating, in the scanning electron microscope. Using the bone marrow of the rat femur, it was shown that this resin-embedding preserved the delicate tissueelements without undesirable dislocation and breakage and assured the eff ective scanning observation as high as $\times 10,000$ at $25 \mathrm{kV}$ accelerating voltage. Passage of blood cells through the sinus wall was thus clearly demonstrated.
\end{abstract}

In our previous papers it was shown that preliminary treatment with tannic acid markedly enhances osmium staining of the biological specimens and affords direct observation and also dissection without charging effect in the scanning electron microscope (MuraKami, 1973, 1974; see also: Irino et al., 1975; W At ANABE et al., 1975).

Our recent experiments have revealed that those intensely osmium-impregnated specimens, even when embedded in resin, can be viewed effectively in the scanning electron microscope. The present paper has a dual purpose. First it will report the utility of resin-embedded samples for scanning electron microscopy and second it will demonstrate transmural passage of blood cells in the bone marrow as confirmed by this method.

\section{Materials and Methods}

Small blocks (about $1 \times 1 \times 3 \mathrm{~mm}$ ) of bone marrow, which were removed from the femurs of the non-irrigated Donryu rats, were fixed for about $8 \mathrm{hr}$ in $5 \%$ formalin in a $0.1 \mathrm{M}$ phosphate buffer ( $\mathrm{pH} 7.4$ ), and impregnated with osmium by the revised tannin-osmium method of Murakami (1974). The blocks were then dehydrated through a graded series of hydroxy ethyl methacrylate, immersed in this resin containing $0.5 \%$ benzoyl peroxide, and placed in an incubator $\left(45^{\circ} \mathrm{C}\right)$.

After hardening of the resin, the specimens were cracked with a chisel or cut by a microtome (Porter-Blum), mounted on metal-stubs (brass), and observed, with neither metal evaporation nor elimination of resin, in a scanning electron microscope (JSMU3) with an acceleration voltage of $25 \mathrm{kV}$.

\section{Results and Discussion}

The biological specimens treated by the revised tannin-osmium method of Murakami (1974), even when embedded in resin, could be viewed in the scanning 


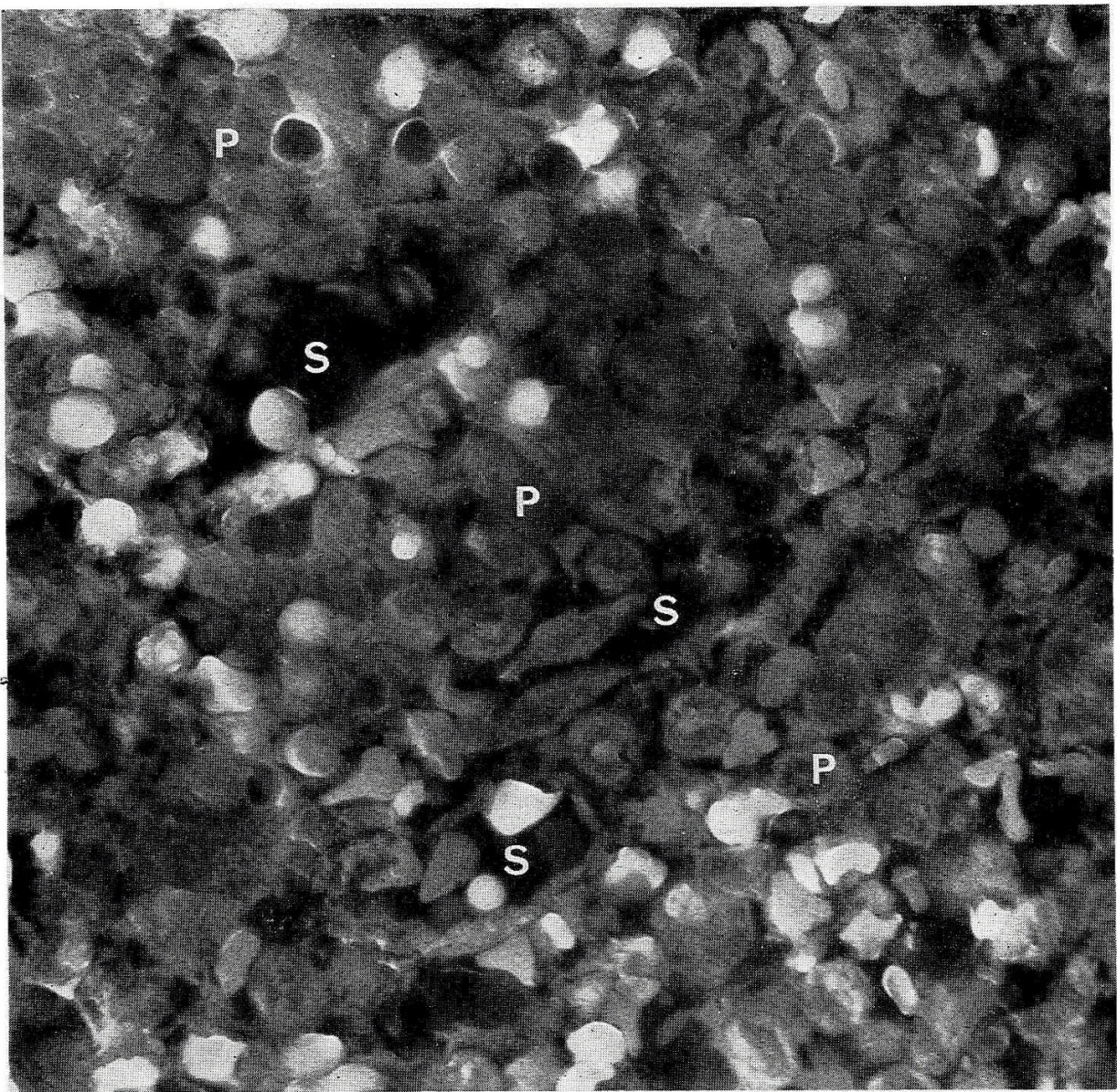

Fig. 1. A scanning electron micrograph of a cracked surface of the tannin-osmium impregnated tissue of bone marrow embedded in hydroxy ethyl methacrylate. Note that no marked charging occurs. $P$ bone marrow parenchyma, $S$ bone marrow sinus. $\times 1,200$

electron microscope. No charging effect was noticed at $25 \mathrm{kV}$. The embedding medium, being earthed by the conductive specimens, showed no charging either (Fig. 1-4).

In the background of dark resin-area with little secondary electron emission, the tannin-osmium specimens were adequately highlighted and could be effectively observed under the magnifications as high as $\times 10,000$ (Fig. 2-4). Owing to the interference of electron beam transmission in resin, the deeply embedded parts of the specimens were obscured in image. In spite of limited visualization into the depth, the present resin-embedded specimens were in an excellent condition with regard to the preservation of fine and fragile structures, which might easily be broken or lost in the usual preparations (see below). As shown in Figure 2, the cracked and strangulated portion of the blood cell $(B B)$ passing through the delicate sinus wall of bone marrow could be preserved without dislocation and breakage. And, as seen in 


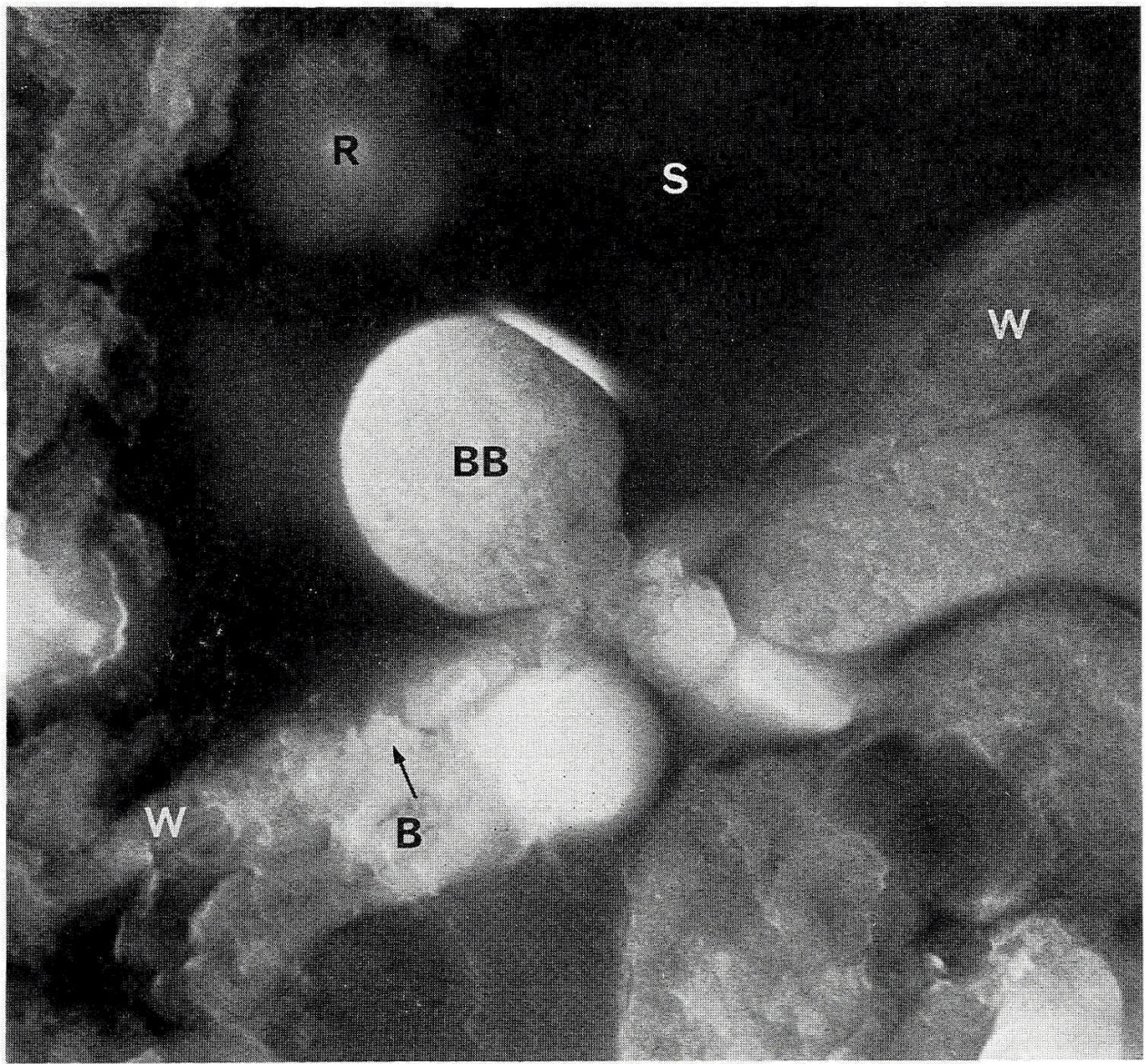

Fig. 2A. A closer view of a sinus-area in Figure 1. Note that the images are adequately contrasted. Deeply located elements such as the cell labeled $R$ is obscured. $B$ and $B B$ red blood cells passing through the sinus wall (see text), $S$ sinus, $W$ sinus wall. The arrow indicates a process of $\mathrm{B}$ cell. $\times 6,000$
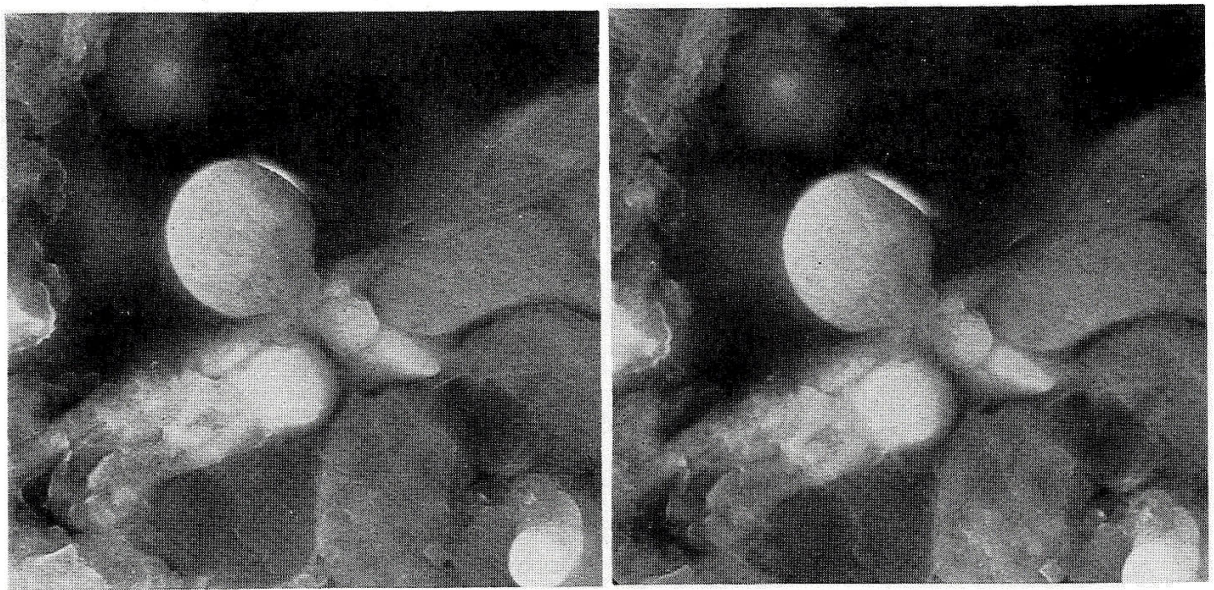

Fig. 2B. Stereo-pair of Figure 2A. $\times 3,000$ 
Figure 3, even a blood cell ( $B B B$ ) floating into the sinus could be kept in its position.

Cracking or cutting was essential to expose the embedded specimens. The surface prepared by cracking was irregular and no consistency was noticed (Fig. 2B,

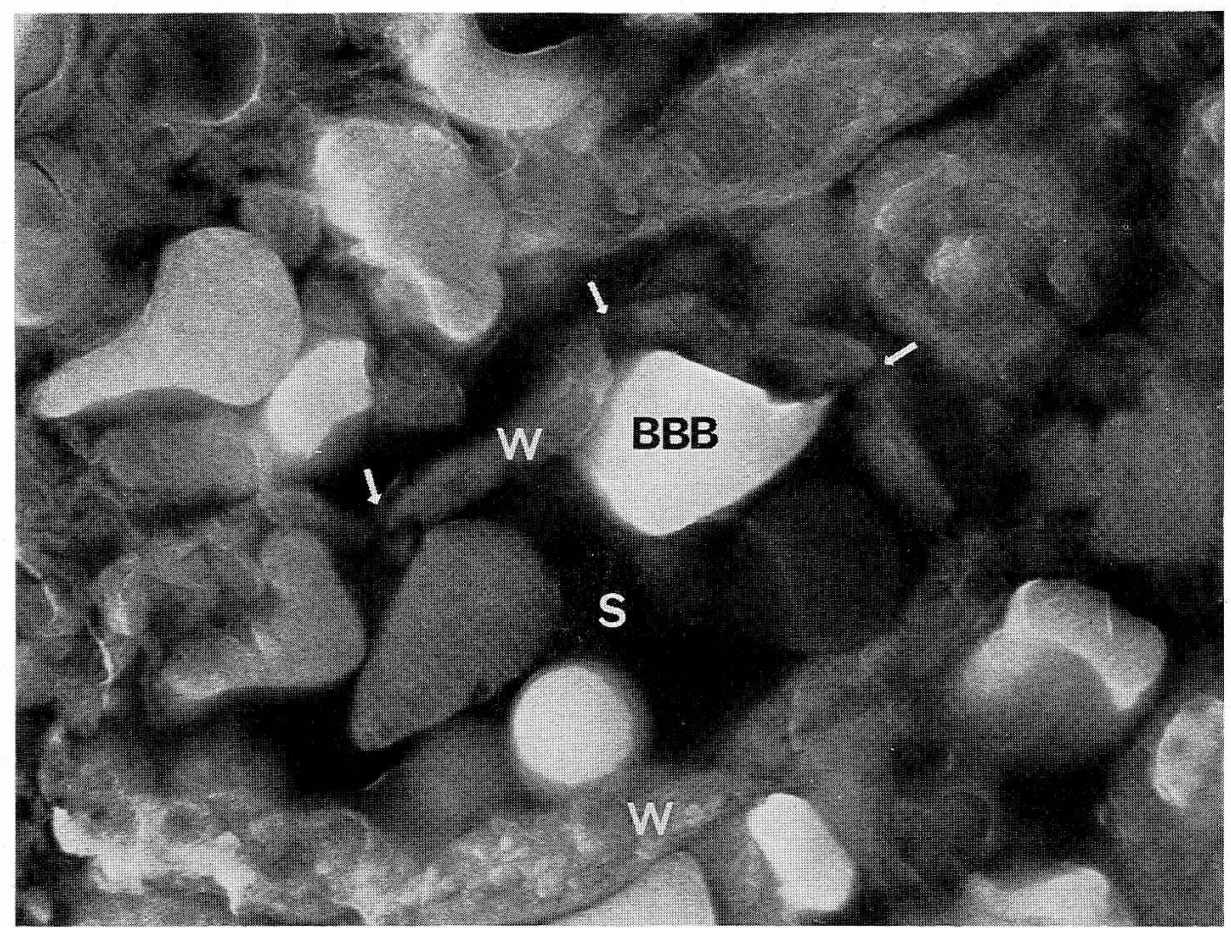

Fig. 3A. A closer view of another area in the sinus shown in Figure 1. $B B B$ a red blood cell apparently finishing its passage into the sinus (see text), $S$ and $W$ (see the legends of Figure 2). The arrows indicate fenestrae of the sinus wall. $\times 3,600$
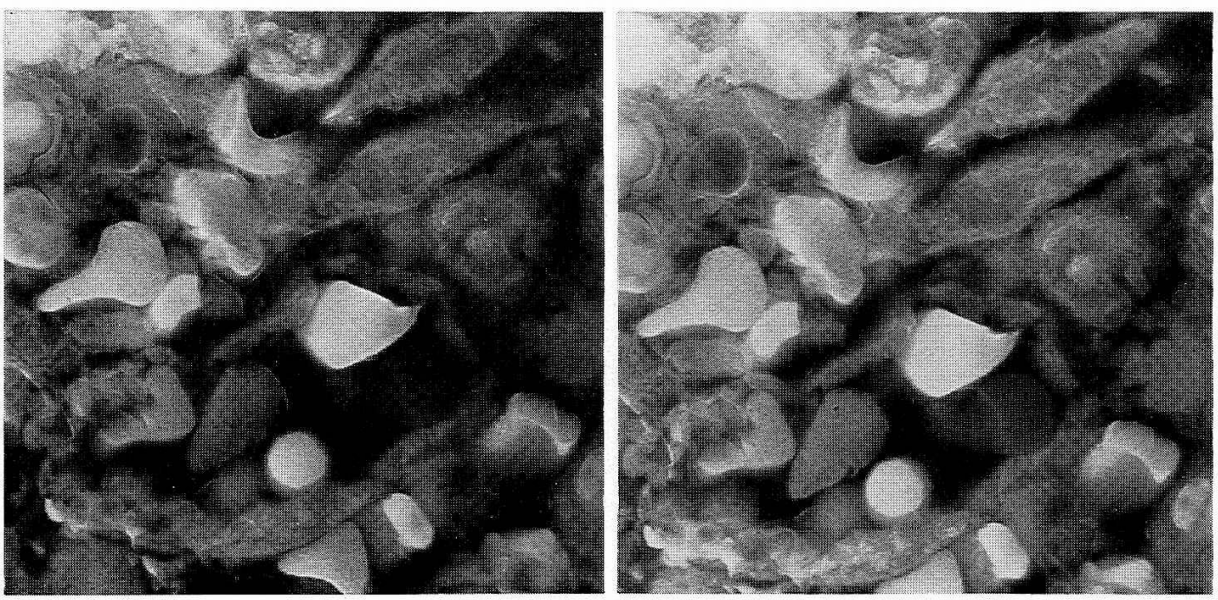

Fig. 3B. Stereo-pair of Figure 3A. $\times 1,800$ 


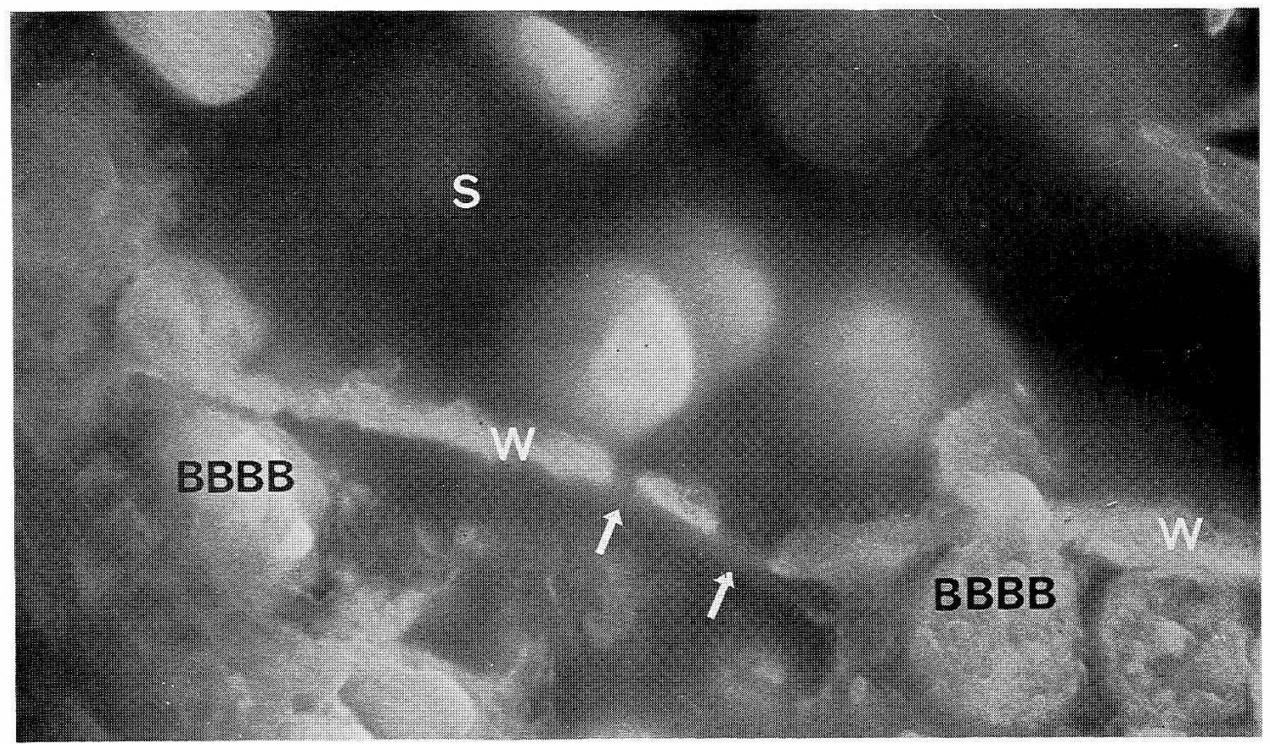

Fig. 4. Scanning electron micrograph of the tannin-osmium treated and resin-embedded bone marrow. $B B B B$ red blood cells in transmural passage, $S$ and $W$ (see the legend of Figure 2). The arrows indicate fenestrae of the sinus wall. $\times 3,600$

3B). Cutting by the microtome prepared a homogeneously flattened surface. Sections were also readily prepared by the microtome. In the scanning of such thin sections, the samples had to be mounted or placed on light metals such as carbon and aluminum with little secondary electron emission to contrast the secondary electron beam from the embedded specimens or to obtain effective images as high as $\times 10,000$.

Recent combination of critical point drying and freeze cracking with epon, ethanol, isoamyl acetate and other anti-crystallization media has exposed clean tissuesurfaces for scanning electron microscopy (see: TANAKA, 1972; ToKUNAGA et al., 1974; and others). TANAKA and NAGURO (1974) prepared styren embedded specimens and, after cracking, removed polymerized styren with isoamyl acetate for critical point drying. ERLANDSEN et al. (1973) eroded polymerized epon with alcohol containing sodium hydroxide. Our preliminary experiments using isoamyl freeze cracking of TokUnAGA et al. (1974) indicated that this kind of preparation, inevitably followed by elimination of embedding media and subsequent handlings including metal evaporation of delicate specimens without protection, is insufficient to preserve fine and fragile tissue-elements exposed in the surface; moreover, such floating cells as shown in Figure 3 are always lost. TANAKA and Kashima (1974) deposited glutaraldehyde-fixed blood cells in egg-albumin, cracked them after hardening of albumin with glutaraldehyde, and demonstrated their albumin-embedded, fractured and metal-evaporated forms under the scanning electron microscope. Our preliminary experiments in the present papar confirmed that this albumin-packing is also of use to protect delicate tissues such as bone marrow though the observation into the depth is completely hindered.

Tousimis (1969) initiated the scanning of resin-embedded specimens though only 
using thin sections. In his method, epon-embedded specimens $(0.2-2.0 \mu$ in thickness $)$ of glutaraldehyde-fixed tissues were placed on quartz, coated with carbon, and scanned without elimination of resin. DeNeE et al. (1974, Fig. 14) showed a scanning micrograph of uranyl- and lead-stained epon sections placed on a copper grid. Our technique using intensely osmium-impregnated specimens which give highly contrasted images, has a great advantage over those of the previous authors only suited to the observations at the highest magnification $\times 3,000-4,000$. KELLEY et al. (1973) developed an osmium-impregnation method using thiocarbohydrazide (also see: MALICK and WiLson, 1975). This method, affording block staining, seems effectively used in the present resin-embedding of non-coated samples. Besides methacrylate, we examined styren and epon as embedding media. These resins were inferior to methacrylate and deteriorated the images.

The scanning electron micrographs shown in this paper demonstrate transmural passage of blood cells in the bone marrow. In Figure 2, the cell $B$, a process of which is inserted in the sinus, probably represents an initial stage of passage and the cell $B B$ likely shows a later stage. The cell $B B B$, which is in the sinus and has a tapered tail directed to a fenestra of the sinus wall, may represent a final stage (Fig. 3). It is noted in Figures 3 and 4 that the fenestrations in the bone marrow sinus wall, which were previously demonstrated in the irrigated specimens (IRINO et al., 1975), are recognized in the present non-irrigated samples. We consider that these fenestrations are intracellular in position and persistently open for preferential pathways of blood cells (also see: Irino et al., 1975). MiYoshi (1975), who studied the rabbit bone marrow by the routine scanning method consisting of perfusion fixation, critical point dring and metal evaporation, described that the formation and dimension of the fenestrations were regulated by the reticular grids on the sinus wall.

Acknowledgement. The author expresses his sincere thanks to Mr. N. HAYASHI, Mr. N. Saihara, Miss T. Maruyama, and Miss A. Shibutani for help in scanning electron microscopy.

\section{タンニンーオスミウム処理し レジン包埋した試料の走査電子顕微鏡像. あわせて骨髄血球遊出の観察}

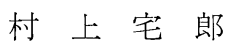

組織片をオスミウム（村上の改良タンニンーオスミウム法 1974）で導電染色し，八イド ロキシエチルメタクリレートに包埋した.レジン包埋した試料は割断し，ただちに走査電 子顕微鏡で観察した.ラットの大腿骨骨髄をもちいて，このレジン包埋法が微弱な組織要 素をよく保存し 加速電圧 $25 \mathrm{kV}$ で 10,000 倍まで効果的に観察できることを示した. かく して骨髄における血球遊出像が明瞭にとらえられた. 


\section{References}

DeNee, P. B., J. L. Abraham and P. A. Willard : Histochemical stains for the scanning electron microscope-qualitative and semi-quantitative aspects of specific silver stains. In: (ed. by) O. Johari and I. Corvin: Scanning electron microscopy/1974. Chicago, IIT Res. Inst., 1974. (p. 259-266).

Erlandsen, S. L., A. Thomas and G. Wendelschafer: A simple techniqhe for correlating SEM with TEM on biological tissue originally embedded in epoxy resin for TEM. In: (ed. by) 0 . Johari and I. Corvin: Scanning electron microscopy/1973. Chicago, IIT Res. Inst., 1973. (p. 349-355).

Irino, S., T. Ono, K. Watanabe, K. Toyota, J. Uno, N. Takasugi and T. Murakami : Scanning electron microscopic studies on microvascular architecture, sinus wall, and transmural passage of blood cells in the bone marrow by a new method of injection replica and noncoated specimens. In: (ed. by) O. Johari and I. Corvin: Scanning electron microscopy/1975. Chicago, IIT Res. Inst., 1975. (p. 267-274).

Kelley, R. O., R. A. F. Dekker and J. G. Bluemink : Ligand-mediated osmium binding: Its application in coating biological specimens for scanning electron microscopy. J. Ultrastr. Res. 45: 254-258 (1973).

Malick, L. E. and R. B. Wilson : Evaluation of a modified technique for SEM examination of. vertebrate specimens without evaporated metal layers. In: (ed. by) O. Johari and I. Corvin: Scanning electron microscopy/1975. Chicago, IIT Res. Inst., 1975. (p. 259-277).

Miyoshi, M.: Scanning electron microscopy of the bone marrow. In: (ed. by) E. Yamada: Proceedings of 10th International Congress of Anatomists. Tokyo, Science Council of Japan, 1975 (p. 362).

Murakami, T.: A metal impregnation method of biological specimens for scanning electron microscopy. Arch. histol. jap. 35: 323-326 (1973).

- 1 A revised tannin-osmium method for non-coated scanning electron microscope specimens. Arch. histol. jap. 36: 189-193 (1974).

Tanaka, K.: Frozen resin cracking method for scanning electron microscopy of biological materials. Naturwiss. 59: 77-78 (1972).

Tanaka, K. and Y. Kashima: The cracking of free cells for scanning electron microscopy (In Japanese). In: (ed. by) K. Tanaka: Reports of the 3rd Japanese Medical SEM Symposium (held at Aso in Kumamoto). 1974 (p. 9-10).

Tanaka, K. and T. Naguro: Styren resin cracking method for scanning electron microscopy (In Japanese). Acta anat. nippon. 49: 13-14 (Abst.) (1974).

Tokunaga, J., M. Edanaga, T. Fujita and K. Adachi : Freeze cracking of scanning electron specimens. A study of the kidney and spleen. Arch. histol. jap. 37: 165-182 (1974).

Tousimis, A. J.: A combined scanning electron microscopy and electron probe microanalysis of biological soft tissues. In: (ed. by) O. Johari: Scanning electron microscopy/1969. Chicago, IIT Res. Inst., 1969. (p. 219-230).

Watanabe, T., T. Nagatani and T. Murakami : New non-coating observation techniques in SEM (In Japanese). The Cell (Tokyo) 7(1): 118-125 (1975).

\section{村上宅郎}

二700 岡山市鹿田町 $2-5-1$

岡山大学医学部

第二解剖学教室
Dr. Takuro Murakami

Department of Anatomy

Okayama University School of Medicine

Okayama, 700 Japan 